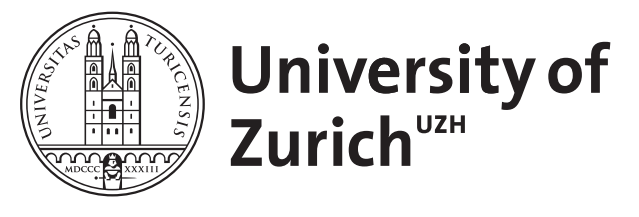

\title{
Prion proteins and infertility: insight from mouse models
}

Genoud, N ; Behrens, A ; Arrighi, I ; Aguzzi, A

\begin{abstract}
A wealth of evidence points to an abnormal form of the prion protein called $\operatorname{PrP}(\mathrm{Sc})$ as the transmissible agent responsible for prion diseases. However, the physiological function of its normal conformer, the cellular prion protein $(\operatorname{PrP}(\mathrm{C}))$, is still unknown. Recently, a homologue of $\operatorname{PrP}(\mathrm{C})$ was discovered and denoted Doppel (Dpl). In contrast to PrP, mice deficient for Dpl suffer from an important pathological phenotype: male sterility. This phenotype shifts the attention from the brain, where most of the investigations on Dpl have been performed, to testis, raising hope to resolve the long lasting search of $\operatorname{PrP}(\mathrm{C})$ function.
\end{abstract}

DOI: https://doi.org/10.1159/000076814

Posted at the Zurich Open Repository and Archive, University of Zurich ZORA URL: https://doi.org/10.5167/uzh-1885

Journal Article

Published Version

Originally published at:

Genoud, N; Behrens, A; Arrighi, I; Aguzzi, A (2003). Prion proteins and infertility: insight from mouse models. Cytogenetic and Genome Research, 103(3-4):285-289.

DOI: https://doi.org/10.1159/000076814 


\title{
Prion proteins and infertility: insight from mouse models
}

\author{
N. Genoud, A. Behrens, I. Arrighi and A. Aguzzi \\ Institute of Neuropathology, UniversitätsSpital Zurich, Zurich (Switzerland)
}

\begin{abstract}
A wealth of evidence points to an abnormal form of the prion protein called $\mathrm{PrPSc}^{\mathrm{S}}$ as the transmissible agent responsible for prion diseases. However, the physiological function of its normal conformer, the cellular prion protein $\left(\operatorname{Pr} \mathrm{PC}^{\mathrm{C}}\right)$, is still unknown. Recently, a homologue of $\mathrm{PrP}^{\mathrm{C}}$ was discovered and denoted Doppel (Dpl). In contrast to PrP, mice deficient
\end{abstract}

for Dpl suffer from an important pathological phenotype: male sterility. This phenotype shifts the attention from the brain, where most of the investigations on Dpl have been performed, to testis, raising hope to resolve the long lasting search of $\mathrm{PrPC}$ function.

Copyright (C) 2003 S. Karger AG, Base

\section{Prion diseases}

Prion diseases are lethal encephalopathies affecting many animal species. Although prion diseases may present with certain morphological and pathophysiological parallels to other progressive encephalopathies, such as Alzheimer's and Parkinson's disease, they are unique in that they are transmissible. In the last decade, the public interest in prions has risen because strong circumstantial evidence (Aguzzi, 1996; Aguzzi and Weissmann, 1996; Collinge et al., 1996; Bruce et al., 1997; Hill et al., 1997) suggests that bovine spongiform encephalopathy (BSE) is the cause of variant Creutzfeldt-Jakob disease (vCJD).

The nature of the infectious agent causing transmissible spongiform encephalopathies (TSEs) is still not completely clear, but may consist essentially of PrPSc, an abnormally folded, protease-resistant, beta-sheet rich isoform of a normal

This work is supported by grants of the Bundesamt für Bildung und Wissenschaft, the Swiss National Foundation, the Department of Defense (USA), and the NCCR on neural plasticity and repair to A.A. N.G. is supported by the Koetser Foundation and I.A. is supported by a long-term fellowship of the European Molecular Biology Organization.

Received 14 October 2003; accepted 4 November 2003.

Request reprints from: Dr. Adriano Aguzzi, Institut für Neuropathologie Universitätsspital Zürich, Schmelzbergstr. 12

CH-8091 Zürich (Switzerland); telephone: +41 12552869

fax: +41 1255 4402; e-mail: adriano@pathol.unizh.ch

Present address of A.B.: Mammalian Genetics Laboratory, Cancer Research UK London Research Institute; Lincoln's Inn Fields Laboratories

44 Lincoln's Inn Fields, London WC2A 3PX (UK). cellular protein termed $\mathrm{PrP}^{\mathrm{C}}$ (Prusiner, 1982). Conversion of $\mathrm{PrPC}^{\mathrm{C}}$, which is expressed abundantly in the central nervous system, to PrPSc, is a central event in prion pathogenesis (Prusiner, 1991). However, the molecular mechanisms of conversion remain unclear. $\mathrm{PrPC}^{\mathrm{C}}$ is essential for the development of prion disease, since its ablation confers resistance to scrapie (Büeler et al., 1993).

After peripheral inoculation, prions colonize the lymphoreticular system where replication of $\mathrm{PrPSc}$ is abundant. Functional follicular dendritic cells are required for prion replication (Montrasio et al., 2000). In the progress of the disease, prions find access to the central nervous system probably through elements of the autonomic nervous system (Glatzel et al., 2001). After reaching the brain, prions cause neuronal loss, astrocytes activation and vacuolation, which are hallmarks of TSEs. However, the mechanisms leading to damage in the brain remain largely unknown.

The discovery of Doppel and its implication in prion disease The recent discovery of Dpl created a stir in the prion field. $\mathrm{Dpl}$ and $\mathrm{PrPC}^{\mathrm{C}}$, while sharing only $25 \%$ identity in primary sequence, have remarkable similarities in the three dimensional structures (Luhrs et al., 2003). Dpl resembles N-terminally truncated PrP: it is GPI anchored, and it has three $\alpha$-helices. However, it has two (rather than one) disulphide bridges between the second and the third helices (Fig. 1). The Prnd gene, which encodes Dpl, is evolutionarily conserved, suggesting an essential biological function (Lu et al., 2000; Silverman et al., 2000; Mo et al., 2001).

\begin{tabular}{lll}
\hline KARGER & $\begin{array}{l}\text { Fax +4161306 12 34 } \\
\text { E-mail karger@karger.ch } \\
\text { www.karger.com }\end{array}$ & ( 2003 S. Karger AG, Basel \\
$0301-0171 / 03 / 1034-0285 \$ 19.50 / 0$
\end{tabular}




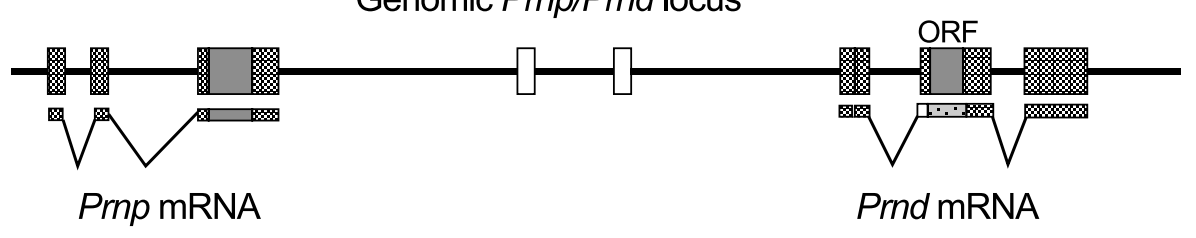

B

Fig. 1. (a) Genomic Prnp/Prnd locus. Genomic exons are represented by rectangles, open reading frames (ORF) by black rectangles and introns by lines. mRNA transcripts generated from the loci are also shown. (b) Structural comparison of $\mathrm{PrPC}^{\mathrm{C}}$ and Doppel. S-S = disulphide bridges; $\mathrm{TM}=$ transmembrane domain; OctaR = octameric repeats. $\mathrm{H} 1, \mathrm{H} 2$ and $\mathrm{H} 3$ rectangles represent alpha-helix 1,2 and 3 respectively.

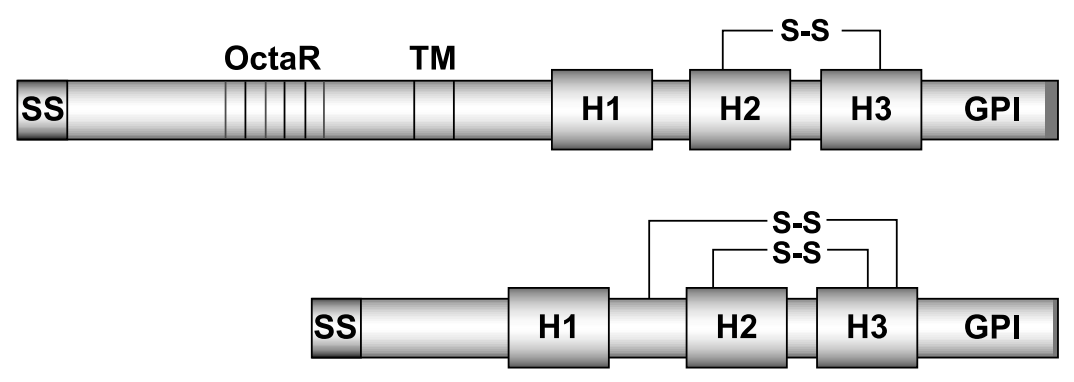

If $\mathrm{Dpl}$ is structurally similar to $\mathrm{PrPC}^{\mathrm{C}}$, is it involved in prion pathogenesis and can it be converted into a $\mathrm{Dp}^{\mathrm{Sc}}$ form? We addressed this question with a neural grafting paradigm. Neural stems cells homozygous for the disruption of the Prnd locus were grafted in the brains of Prnp knockout mice. The Prnd null grafts were found to undergo normal neural differentiation, ruling out an important function of Dpl during brain development. After inoculation with scrapie, grafts lacking Prnd showed unimpaired prion pathogenesis and an infectivity level similar to wild-type grafts (Behrens et al., 2001). Similarly, overexpression of $\mathrm{Dpl}$ in the brain of transgenic mice does not modulate prion pathogenesis (Tuzi et al., 2002). Several groups have searched for possible linkage disequilibria of Prnd alleles in human prion disease but no polymorphisms were found to be associated with them (Mead et al., 2000; Peoc'h et al., 2000). Interestingly, a relation between a cluster of familial CJD mutations and the structure of $\mathrm{Dpl}$ has been described. These F-CJD alleles may cause mutant PrP to become a weak mimetic of Dpl structure or function (Mastrangelo et al., 2002).

Dpl resembles an N-terminally truncated $\mathrm{PrPC}^{\mathrm{C}}$ protein lacking the octamer repeats (Fig. 1b). The latter version of $\operatorname{PrPC}^{\mathrm{C}}$ is actually capable of supporting PrPsc propagation, suggesting that Dpl protein could be susceptible to conversion into "Dplsc" (Flechsig et al., 2000). However, presently no evidence suggests any conversion of Dpl into a misfolded beta-strandrich, protease-resistant conformation and any implication in prion pathogenesis.

\section{The physiological function of $\operatorname{PrP}^{C}$}

The physiological role of $\mathrm{PrPC}^{\mathrm{C}}$ is still unclear. So far, the functions attributed to $\mathrm{PrPC}^{\mathrm{C}}$ are disparate and quite confusing: they include a membrane receptor, an effector in signal transduction, a regulator of apoptosis, a copper binding protein, and a regulator of synaptic transmission, among others.

Postnatal ablation of PrP does not result in neurodegeneration (Mallucci et al., 2002); hence prion pathology is unlikely to be caused by simple loss of PrPC. However, the unknown func- tion of $\mathrm{PrPC}$, upon conversion to $\mathrm{PrPSc}^{\mathrm{S}}$, could be altered or rendered unspecific and this may be one cause of neurodegeneration. Therefore, elucidation of the physiological function of PrP is of highest importance and may be crucial for understanding prion diseases (Aguzzi and Heikenwalder, 2003).

To achieve this goal, several efforts have been dedicated to the identification of prion binding proteins. In fact, many candidates have been found, but none of them has revealed any in vivo function in which $\mathrm{PrPC}^{\mathrm{C}}$ would be involved. Also, the $\mathrm{PrP}$ binding partners are disparate and, as a whole, rather confusing. For example, PrP was reported to bind to transmembrane proteins (N-CAM, laminin receptor, dystroglycan complex) (Keshet et al., 2000; Gauczynski et al., 2001; Schmitt-Ulms et al., 2001) and to apoptotic molecules (Bax, Bcl-2) (Kurschner and Morgan, 1995; Bounhar et al., 2001). None of these binding partners have been shown to be implicated in prion pathogenesis. Despite considerable efforts aimed at connecting $\operatorname{PrP}^{\mathrm{C}}$ with partners with known functions, a clear-cut understanding of $\operatorname{PrPC}^{\mathrm{C}}$ function is still lacking.

\section{$\operatorname{PrP} P^{C}$ and testis}

Research on $\mathrm{PrP}^{\mathrm{C}}$ has been largely focused to the brain, where $\operatorname{PrPC}^{\mathrm{C}}$ is expressed at high levels. However, $\operatorname{PrPC}$ is expressed in many peripheral tissues, and investigation of its role in specific peripheral tissues might help in assign it a specific function. In mouse testis, PrP mRNA is detected in Sertoli cells, primary and secondary spermatocytes, and spermatids in the seminiferous tubules. Protein expression is highest in the cytoplasm of the head of maturing spermatozoa, in the ductus deferens and epididymis, and in the cytoplasmic droplet excluded from the spermatozoan head during maturation (Ford et al., 2002). $\operatorname{PrP}^{\mathrm{C}}$ is present in mature sperms and, in contrast to processing in other cells, $\mathrm{PrPC}^{\mathrm{C}}$ is truncated in sperm cells in its carboxy terminus and lack a glycosyl phosphatidyl inositol (GPI) anchor. Therefore, during sperm maturation, $\operatorname{PrPC}^{\mathrm{C}}$ changes from its regular GPI anchored form to a carboxy terminally truncated peptide no longer associated with membrane 


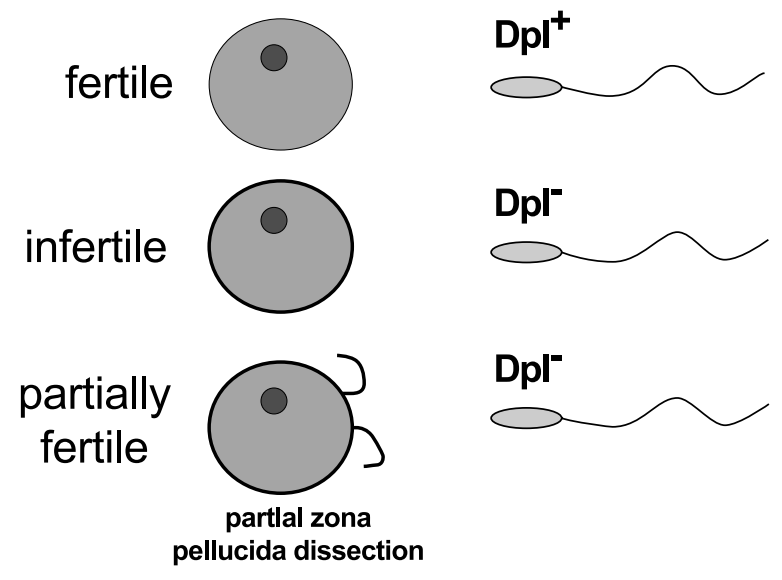

B

Fig. 2. A possible model for the function of Dpl in fertilization. (a) Male sterility in mice that lack Doppel may be due to the incapability of Doppel deficient sperm to fertilize eggs. The process that appears to be disturbed relates to the acrosomal reaction and to the penetration of the zona pellucida. In fact, mechanical dissection of the zona pellucida restores, at least in part, fertility. (b) Interestingly, haploid spermatozoa lacking the Doppel gene $\left(\operatorname{Prnd}^{\circ}\right)$ are perfectly fertile when generated in the context of a heterozygous Prnd ${ }^{+/ o}$ mouse. Instead, Prnd ${ }^{\circ}$ sperm are infertile when generated in a Prnd ${ }^{o / o}$ mouse. Prno sperm, which lack $\mathrm{PrP}^{\mathrm{C}}$ and $\mathrm{Dpl}$, are also infertile.

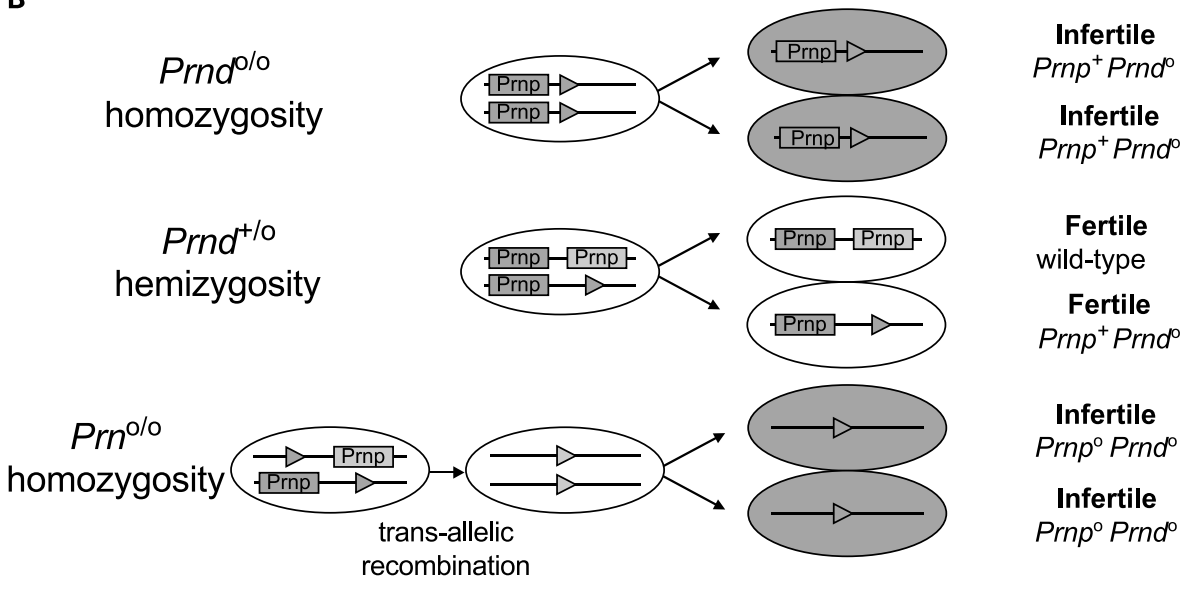

rafts. However, mutant mice lacking PrP are fertile and give birth with a normal litter size. $\operatorname{PrPC}^{\mathrm{C}}$ was also reported to protect sperm cells during specific stress situations (Shaked et al., 1999). This would be consistent with the fact that the absence of $\mathrm{PrPC}^{\mathrm{C}}$ in $\mathrm{PrP}$ deficient mice does not cause any major apparent damage and does not result in male sterility (Büeler et al., 1992).

\section{Physiological function of Dpl in testes}

$\mathrm{Dpl}$ is expressed strongly in testis and heart, at lower levels in spleen and skeletal muscle and is absent in brain of wild-type mice. However, significant levels of Prnd mRNA have been detected during embryogenesis and in the brain of newborn mice (Li et al., 2000).

In mouse testis, Dpl expression is detected in stage specific manner in spermatids (Behrens et al., 2002). In humans, Dpl is present in Sertoli cells, on the flagella of spermatozoa and seminal plasma (Peoc'h et al., 2002).

To investigate the physiological function of Dpl, we generated mutant mice lacking Dpl. The mutants develop normally and have a normal behavior, yet knockout males are infertile. The overall histological appearance of Dpl deficient testes was normal: we found normal distribution and counts of spermato- gonia, spermatocytes and Sertoli cells. However, mature spermatozoa from mutant mice were reduced in numbers, less mobile, mostly malformed and unable to fertilize oocytes in vitro. Many Prnd ${ }^{\text {neo/neo }}$ sperm head were lacking a discernible acrosome. Only after partial disruption of the zona pellucida was in vitro fertilization of Prnd ${ }^{\text {neo/neo }}$ partially restored, therefore implicating acrosome malformation as a crucial reason for sterility (Fig. 2) (Behrens et al., 2002).

The molecular mechanism of Dpl action on the acrosome is unclear. Dpl may be present at the acrosome surface through its GPI anchor and may be directly involved in sperm-egg interaction. If this appears to be true, anti-Dpl antibodies might block in vitro fertilization of wild-type sperm. Alternatively, Dpl might be required for normal morphogenesis of acrosome during development or to trigger acrosomal reaction. Sperm malformation could result from a failure in acrosome biogenesis. A better characterization of Dpl function is required and identification of Dpl partners could help; in contrast to PrP, so far none have been identified for Dpl.

Do PrP and Dpl accomplish redundant functions?

The similarities between $\operatorname{PrP}^{\mathrm{C}}$ and $\mathrm{Dpl}$ in primary amino acid sequence, structure and subcellular localization suggest 

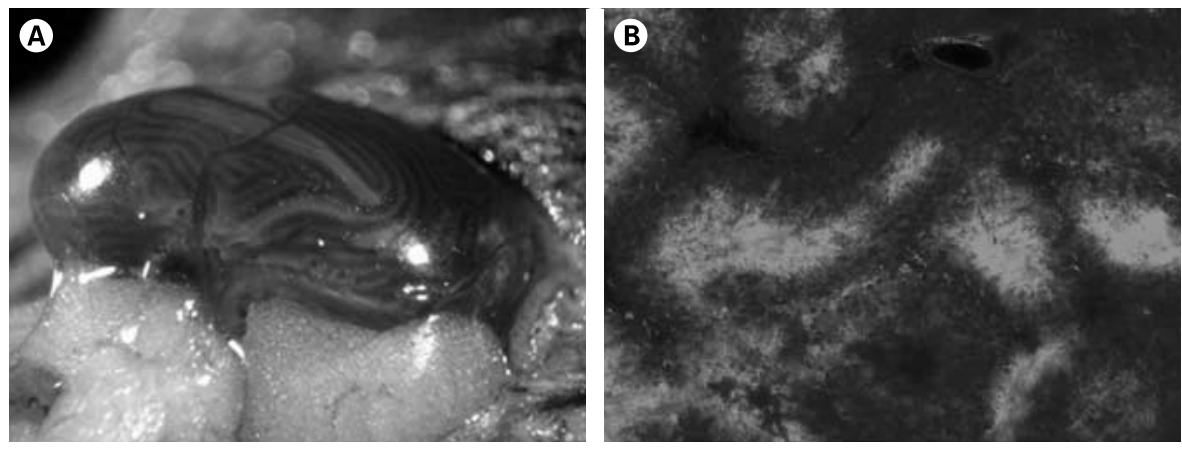

Fig. 3. Injection of lentivirus into the testis. (a) Lentivirus was injected into the right testis. Trypan blue was added to the solution in order to visualize the injected material. Most seminiferous tubules can be reached by this technique, as indicated by the translucent blue stain. (b) Under fluorescence, trypan blue (which emits red light) can be detected within the seminiferous tubuli of testicular frozen sections. (c-d) $\beta$-Galactosidase staining on mouse testis cryosections injected with a lentiviral vector that encodes lac Z (c) and mock-inoculated control testis (d). Both mice were sacrificed one month after injection.
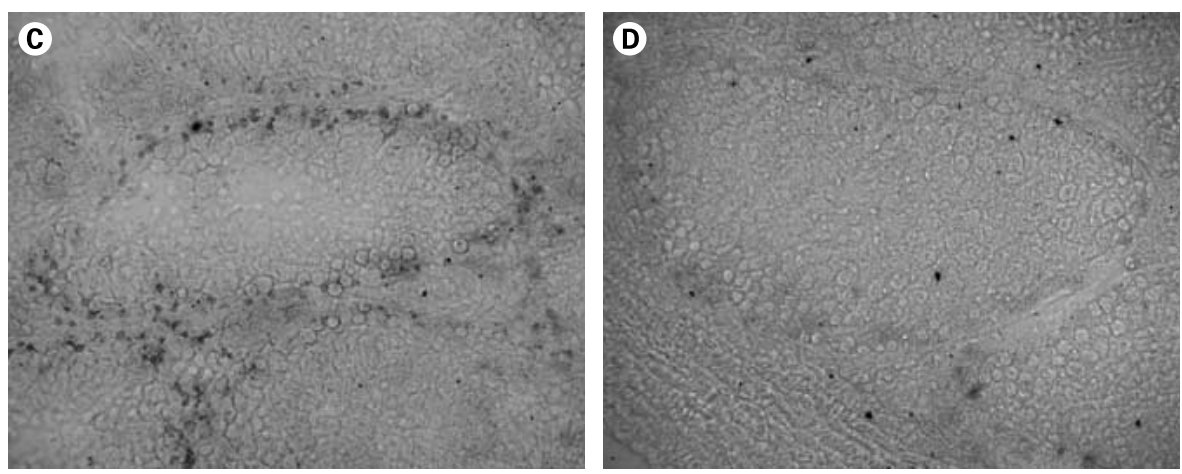

related biological functions (Mo et al., 2001; Behrens and Aguz$\mathrm{zi}$, 2002). Therefore, a possible role of $\mathrm{PrPC}^{\mathrm{C}}$ and $\mathrm{Dpl}$ during development may be masked by functional redundancy. The presence of Dpl could also mask a minor function of $\mathrm{PrPC}^{\mathrm{C}}$ in testis or more strongly affect spermatogenesis.

Therefore, we generated $\mathrm{Prn}^{\mathrm{o} / \mathrm{o}}$ mutant mice lacking both $\mathrm{PrPC}^{\mathrm{C}}$ and Dpl. We took advantage of trans-allelic meiotic recombination (Herault et al., 1998), showing that this strategy is not restricted to specific loci and can be widely used as a powerful genetic tool for complex genomic applications.

Suprisingly, the double mutant $\mathrm{Prn}^{\mathrm{o} / \mathrm{o}}$ mice do not show any obvious abnormalities apart from male infertility, and morphological analyses of sperm do not provide evidence for a difference in phenotype compared to the single mutant Prnd ${ }^{\text {neo/neo }}$ mice. It appears therefore that disruption of PrP in Dpl deficient mice does not induce any obvious histological abnormalities, and fails to accentuate the sperm phenotype. Thus, developmental expression of Dpl does not compensate and suppress any pathological brain phenotype that might have been brought about by the absence of $\mathrm{PrP}^{\mathrm{C}}$. We conclude that the mild phenotypes that are described in mice lacking $\mathrm{PrP}^{\mathrm{C}}$ are unlikely due to functional compensation by Dpl.

The lack of redundancy is surprising in the light of the high structural similarity between $\mathrm{PrP}^{\mathrm{C}}$ and Dpl (Fig. 1b) and the evolutionary conservation of both proteins. Therefore, it is conceivable that there are additional as yet unidentified proteins belonging to the $\mathrm{PrPC} / \mathrm{Dpl}$ protein family that have retained a structure similar to $\mathrm{PrPC}^{\mathrm{C}}$ and $\mathrm{Dpl}$.

Reverse genetics using lentiviral vectors

Significant progress has been made recently in the realm of in vivo gene delivery to the testis. The newly developed testis cell transplantation (Brinster, 2002) and viral-vector mediated gene transfer provide powerful tools to examine spermatogenic defects, to generate transgenic animals, and even to correct male infertility. Recently, restoration of spermatogenesis by lentiviral gene transfer has been achieved in infertile mice (Ikawa et al., 2002). We are using a similar approach in our laboratory. Testes transduced with a replication-defective lentiviral vector encoding lac $\mathrm{Z}$ were positive for $\beta$-gal staining (Fig. 3). We intend to take advantage of this technique to study the reverse genetics of Dpl. We are now transducing testes from $P r n d^{\text {neo/neo }}$ or $\mathrm{Prn}^{\mathrm{o} / \mathrm{o}}$ mice with lentiviruses encoding full-length Dpl or different truncated versions of Dpl. Subsequently, we are studying the possible restoration of fertility by mating transduced males, and/or by performing in vitro fertilization. This technique has an excellent potential for yielding crucial information about the function of Dpl while obviating for the expensive and time-consuming need to generate new transgenic mouse lines.

\section{Acknowledgements}

We thank Mrs. Petra Schwarz for technical help. 


\section{References}

Aguzzi A: Between cows and monkeys. Nature 381:734 (1996).

Aguzzi A, Heikenwalder M: Prion diseases: Cannibals and garbage piles. Nature 423:127-129 (2003).

Aguzzi A and Weissmann C: Spongiform encephalopathies: a suspicious signature. Nature 383:666-667 (1996).

Behrens A, Aguzzi A: Small is not beautiful: antagonizing functions for the prion protein $\operatorname{PrP}(C)$ and its homologue Dpl. Trends Neurosci 25:150-154 (2002).

Behrens A, Brandner S, Genoud N, Aguzzi A: Norma neurogenesis and scrapie pathogenesis in neura grafts lacking the prion protein homologue Doppel. EMBO Rep 2:347-352 (2001)

Behrens A, Genoud N, Naumann H, Rulicke T, Janett F, Heppner FL, Ledermann B, Aguzzi A: Absence of the prion protein homologue Doppel causes male sterility. EMBO J 21:3652-3658 (2002).

Bounhar Y, Zhang Y, Goodyer, CG, LeBlanc A: Prion protein protects human neurons against Bax-mediated apoptosis. J biol Chem 276:39145-39149 (2001).

Brinster RL: Germline stem cell transplantation and transgenesis. Science 296:2174-2176 (2002).

Bruce ME, Will RG, Ironside JW, McConnell I, Drummond D, Suttie A, McCardle L, Chree A, Hope J, Birkett, C, Cousens S, Fraser H, Bostock CJ Transmissions to mice indicate that "new variant" CJD is caused by the BSE agent. Nature 389:498501 (1997).

Büeler HR, Aguzzi A, Sailer A, Greiner RA, Autenried $\mathrm{P}$, Aguet M, Weissmann C: Mice devoid of PrP are resistant to scrapie. Cell 73:1339-1347 (1993).

Büeler HR, Fischer M, Lang Y, Bluethmann H, Lipp HP, DeArmond SJ, Prusiner SB, Aguet M, Weissmann C: Normal development and behaviour of mice lacking the neuronal cell-surface PrP protein. Nature 356:577-582 (1992)

Collinge J, Sidle KC, Meads J, Ironside J, Hill AF Molecular analysis of prion strain variation and the aetiology of "new variant" CJD. Nature 383:685690 (1996).

Flechsig E, Shmerling D, Hegyi I, Raeber AJ, Fischer M, Cozzio A, von Mering C, Aguzzi A, Weissmann $\mathrm{C}$ : Prion protein devoid of the octapeptide repeat region restores susceptibility to scrapie in $\operatorname{PrP}$ knockout mice. Neuron 27:399-408 (2000).

Ford MJ, Burton LJ, Morris RJ, Hall SM: Selective expression of prion protein in peripheral tissues of the adult mouse. Neuroscience 113:177-192 (2002).
Gauczynski S, Peyrin JM, Haik S, Leucht C, Hundt C, Rieger R, Krasemann S, Deslys JP, Dormont D, Lasmezas CI, Weiss S: The 37-kDa/67-kDa laminin receptor acts as the cell-surface receptor for the cellular prion protein. EMBO J 20:5863-5875 (2001).

Glatzel M, Heppner FL, Albers KM, Aguzzi A: Sympathetic innervation of lymphoreticular organs is rate limiting for prion neuroinvasion. Neuron 31:2534 (2001).

Herault Y, Rassoulzadegan M, Cuzin F, Duboule D: Engineering chromosomes in mice through targeted meiotic recombination (TAMERE). Nat Genet 20:381-384 (1998).

Hill AF, Desbruslais M, Joiner S, Sidle KC, Gowland I, Collinge J, Doey LJ, Lantos P: The same prion strain causes vCJD and BSE. Nature 389:448-450 (1997).

Ikawa M, Tergaonkar V, Ogura A, Ogonuki N, Inoue K, Verma IM: Restoration of spermatogenesis by lentiviral gene transfer: offspring from infertile mice. Proc natl Acad Sci USA 99:7524-7529 (2002).

Keshet GI, Bar-Peled O, Yaffe D, Nudel U, Gabizon R: The cellular prion protein colocalizes with the dystroglycan complex in the brain. J Neurochem 75 : 1889-1897 (2000).

Kurschner C, Morgan JI: The cellular prion protein (PrP) selectively binds to Bcl-2 in the yeast twohybrid system. Brain Res 30:165-168 (1995).

Li A, Sakaguchi S, Shigematsu K, Atarashi R, Roy BC, Nakaoke R, Arima K, Okimura N, Kopacek J, Katamine S: Physiological expression of the gene for PrP-like protein, PrPLP/Dpl, by brain endothelial cells and its ectopic expression in neurons of PrP- deficient mice ataxic due to purkinje cell degeneration [In Process Citation]. Am J Pathol 157:1447-1452 (2000)

Lu K, Wang W, Xie Z, Won, BS, Li R, Petersen RB, Sy MS, Chen SG: Expression and structural characterization of the recombinant human doppel protein. Biochemistry 39:13575-13583 (2000).

Luhrs T, Riek R, Guntert P, Wuthrich K: NMR structure of the human doppel protein. J Mol Biol 326: 1549-1557 (2003).

Mallucci GR, Ratte S, Asante EA, Linehan J, Gowland I, Jefferys JG, Collinge J: Post-natal knockout of prion protein alters hippocampal CA1 properties, but does not result in neurodegeneration. EMBO J 21:202-210 (2002).

Mastrangelo P, Serpell L, Dafforn T, Lesk A, Fraser P, Westaway D: A cluster of familial CreutzfeldtJakob disease mutations recapitulate conserved residues in Doppel: a case of molecular mimicry? FEBS Lett 532:21-26 (2002).
Mead S, Beck J, Dickinson A, Fisher EM, Collinge J: Examination of the human prion protein-like gene doppel for genetic susceptibility to sporadic and variant Creutzfeldt-Jakob disease. Neurosci Lett 290:117-120 (2000).

Mo H, Moore RC, Cohen FE, Westaway D, Prusiner SB, Wright PE, Dyson HJ: Two different neurodegenerative diseases caused by proteins with similar structures. Proc natl Acad Sci USA 98:2352-2357 (2001).

Montrasio F, Frigg R, Glatzel M, Klein MA, Mackay F, Aguzzi A, Weissmann C: Impaired prion replication in spleens of mice lacking functional follicular dendritic cells. Science 288:1257-1259 (2000).

Peoc'h K, Guerin C, Brandel JP, Launay JM, Laplanche JL: First report of polymorphisms in the prion-like protein gene (PRND): implications for human prion diseases. Neurosci Lett 286:144-148 (2000).

Peoc'h K, Serres C, Frobert Y, Martin C, Lehmann S, Chasseigneaux S, Sazdovitch V, Grassi J, Jouannet P, Launay JM, Laplanche JL: The human "prionlike" protein Doppel is expressed in both Sertoli cells and spermatozoa. J biol Chem 277:4307143078 (2002).

Prusiner SB: Novel proteinaceous infectious particles cause scrapie. Science 216:136-144 (1982).

Prusiner SB: Molecular biology of prion diseases. Science 252:1515-1522 (1991).

Schmitt-Ulms G, Legname G, Baldwin MA, Ball HL, Bradon N, Bosque PJ, Crossin KL, Edelman GM, DeArmond SJ, Cohen FE, Prusiner SB: Binding of neural cell adhesion molecules (N-CAMs) to the cellular prion protein. J Mol Biol 314:1209-1225 (2001).

Shaked Y, Rosenmann H, Talmor G, Gabizon R: A Cterminal-truncated $\mathrm{PrP}$ isoform is present in mature sperm. J biol Chem 274:32153-32158 (1999).

Silverman GL, Qin K, Moore RC, Yang Y, Mastrangelo $P$, Tremblay $P$, Prusiner SB, Cohen FE, Westaway D: Doppel is an N-glycosylated, glycosylphosphatidylinositol-anchored protein. Expression in testis and ectopic production in the brains of Prnp(0/0) mice predisposed to Purkinje cell loss. J biol Chem 275:26834-26841 (2000).

Tuzi NL, Gall E, Melton D,Manson, JC: Expression of doppel in the CNS of mice does not modulate transmissible spongiform encephalopathy disease. J Gen Virol 83:705-711 (2002). 